\title{
THE CHARACTERISTICS OF AL-QUR'AN INTERPRETATION IN RADICAL ISLAMIC SITES IN INDONESIA
}

\author{
M. Nurdin Zuhdi \\ Universitas 'Aisyiyah Yogyakarta \\ m.nurdinzuhdi@unisayogya.ac.id
}

\section{Mahfudz Masduki}

UIN Sunan Kalijaga Yogyakarta mahfudzmasduki26@gmail.com

\begin{abstract}
The issue of radicalism has become a serious topic in recent years. The issue of radicalism is not only studied at the national level, but also receives a lot of attention at the global level. Radicalism seems to be considered as a virus endangering humanity. Printed and electronic media are allegedly one of the most effective methods of disseminating the understanding of radicalism. The study examines the characteristics of the interpretation of the verses of the Qur'an in Islamic sites which are indicated to adhere to radicalism. The study also examines the extent of the implications of interpreting the verses of the Qur'an in Islamic sites against the spread of the thoughts of radical Islam in Indonesia. The study is included in the library research category with a media analysis approach. The study focuses on interpreting the verses of the Qur'an embraced in Islamic sites in Indonesia. The research is qualitative in nature. From the analysis carried out on five Islamic sites in Indonesia, four interpretive criteria have been found, namely: interpretation as a mean of ideological legitimacy; loss of contextualization of verses; jihadist interpretations campaign; and the typology of revivalist subjectivists in the typology of interpretation. Thie study concludes that media, both printed and electronic, can influence and change the paradigm of thinking that it can move certain people or groups of people to act or behave in a certain way. Thus, it is obvious that the interpretations of the Qur'an in the Islamic sites indicated as radical can have an influence on the spread of radical Islam.
\end{abstract}


Abstrak : Isu tentang radikalisme menjadi topik bahasan yang serius dalam beberapa tahun terakhir ini. Isu radikalime bukan hanya dikaji ditingkat nasional, namun juga banyak meyita perhatian ditingkat global. Radikalisme seolah-olah dianggap sebagai virus yang membahayakan umat manusia. Media cetak maupun elektronik disinyalir sebagai salah satu metode yang ampuh dalam menyebarkan paham radikalisme ini. Penelitian ini mengkaji tentang karakteristik penafsiran ayat-ayat alQur'an dalam situs-situs Islam yang terindikasi menganut paham radikalisme. Penelitian ini juga mengkaji sejauh mana implikasi penafsiran ayat-ayat al-Qur'an dalam situs-situs Islam tersebut terhadap penyebaran pimikiran Islam radikal di Indonesia. Penelitian ini adalah termasuk kategori penelitian pustaka (library research) dengan pendekatan analisis media dengan fokus terhadap penafsiran ayat-ayat al-Qur'an yang ada di dalam situs-situs Islam di Indoneisa. Penelitian ini juga tampak dengan jelas bersifat kualitatif. Dari analisis yang telah dilakukan terhadap lima situs-situs Islam di Indonesia, telah ditemukan empat kriteria penafsiran, yaitu: tafsir sebagai alat legitimasi ideologi; hilangannya kontekstualisasi ayat; mengusung penafsiran jihadis; dan tipologi tafsir yang dihasilkan adalah tipologi subjektivis revivalis. Penelitian ini menyimpulkan bahwa media, baik cetak maupun elektronik, dapat mempengaruhi dan merubah paradigma berfikir sehingga dapat menggerakkan seseorang atau kelompok masyarakat tertentu untuk bertindak maupun berperilaku tertentu. Sehingga jelas bahwa, penafsiran al-Qur'an dalam situs-situs Islam yang terindikasi menganut paham radikal, dapat memberikan pengaruh terhadap penyebaran paham Islam radikal.

Keywords : Islamic Site, Interpretation, Radicalism

\section{A. Introduction}

Islamic Radicalism issue has been re-emerged and become a center of discussion in Indonesia recently. This occurred especially since the Ministry of Communication and Information (Komenkominfo) in March 2015 admitted that it had blocked 19 Islamic sites that were considered to have spread radicalism or sympathizers. In fact, radicalism issue has occurred since long time ago and gets more serious attention in global level. ${ }^{1}$ The serious attention became even more serious after the World

${ }^{1}$ Read, Greg Fealy \& Aldo Borgu, Local Jihad: Radical Islam and Terrorism in Indonesia (Canberra: 2005, Australian Strategic Policy Institute); Quintan Wiktorowicz, Radical Islam Rising: Muslim Extremisn in the West, (Boulder, Toronto and Oxford: 2005 
Trade Centre and Pentagon tragedy in New York on September $11^{\text {th }} 2001$ in which radical Islam group, Al Qaeda and Taliban was accused as the mastermind behind the historic tragedy. Since then, discussion on terrorism and radical Islam has become more globalized. In addition, since the tragedy, public spotlight on Muslim has become increasingly negative. Moreover, in Indonesia alone, there are many terrorism cases by committing suicide bombing in recent years. Especially in more recent times, it is worsen by the emergence of transnational terrorist movement Iraq and Syria (ISIS). The latest incident was on Saturday, November $13^{\text {th }}$ 2015 in which Paris was rocked by bombings which killed more than 150 people.

The radicalism movements are identical with the terms of strict group, extremists, militants, right wing Islam, fundamentalists until terrorism. ${ }^{3}$ The spread of radical Islamic ideology which has been identical to terrorists group and some strict militants groups has been done clandestinely and even now has penetrated openly through online media such as websites, blogs, Twitter, Facebook, and others. Some of the websites or these Islamic websites has been considered that they have spread radical ideology. ${ }^{4}$ Through online media, Islamic interpretation with radical ideology can be detected. Some opinions and or Qur'anic verses interpretation articles published in the sites reflect ideological messages about to be conveyed to its readers. Some of the interpretations brought by the sites are as follows; jihad issue, Islamic laws implementation, Khilafah Islamiyyah, democracy refusal, religion pluralism refusal, gender equality refusal, and etc. ${ }^{5}$

The sites are suspected of being supporters of the transnational terrorist movement Iraq and Syria (ISIS). The sites are also regarded as Islamic sites which consistently spread violent ideology on behalf of religion. If carefully examined, these radical Islamist movements have the same principle, namely to establish an Islamic state with Islamic leadership (Khilafah Islamiyah) and total implementation of Islamic laws. According to these movements, the concept of din al-dawlah (Islamic state) is laying

Rowman \& Littlefield Publishers, Inc); M. Zaki Mubarak, Genealogi Islam Radikal di Indonesia: Ideologi, Pemikiran dan Prospek Demokrasi, (Jakarta: LP3ES, 2008); Woodward, dkk., "Muslim Education, Celebrating Islam and Having Fun As CounterRadicalization Strategies in Indonesia", Perspectives on Terrorism: A Journal of the Terrorism Research Initiative, 4. 4. (2010), P. 42. 
Islamic foundations of the state namely $\mathrm{Al}$ Qur'an and Prophet's teachings as well as the tradition of the companions, scheduling puritanism ideology, laying the state's sovereignty and law on sharia (Islamic laws), resisting Western domination and unfair relation between Islamic world and West, and using jihad as the way to acquire Nizam Islami. ${ }^{6}$ The holistic point of view, according to Imdadun produces the concept that Islam and state cannot be divided. Islam is din wa dawlah (religion and state).

The existence of Islamic sites in Indonesia amid the issue of Iraq and Suriah transnational terrorist groups with an ideological and radical interpretation of Islam is very fundamental to analyze in order to reveal the dialectic that occurs between the practice of interpretation of $\mathrm{Al}$ Qur'an and the implication on the spread of radical comprehension in Indonesia as well as the causal factors. It has to be realized that the practice of interpretation on $\mathrm{Al}$ Qur'an verses in the Islamic sites, from socio-cultural point of view, is not merely a result of understanding God's message but also the arena for interpreters to make a reading of the surrounding sociopolitical realities. ${ }^{7}$ This is what Gadamer emphasizes that in the process of interpretation, pre-understanding always plays roles. Pre-understanding is also influenced by dominant culture where the interpreter lives as well as prejudices (Vorurteile; initial estimate) formed in the tradition. ${ }^{8}$ Based on the explanation, a study discussing about the problem of radicalism in Islamic sites becomes very important especially in the era of information and technology in which fundamental changes occur amid the speed of information developing in the society and the need for understanding of interpretation which leads to Islam which is rohmatan lil 'aalamiin (blessings for the universe).

The outbreak of radicalism issue has invited many researchers to investigate the problem. Among the researches are a study by Syamsul Bakri entitled "Islam and Contemporary Religious Radicalism Discourse"; Syamsul Rizal's research entitled "Classic and Contemporary Islamic Radicalism: Comparing Khawarij and Hisbut Tahrir"; ${ }^{10}$ Ayub Mursalin dan Ibnu Katsir's research entitled "Islamic Boarding School Religious Education Style and Radicalism: A Case Study of Islamic Boarding Schools in Jambi Province"; ${ }^{11}$ Aguk Irawan Mizan with his research entitled "Tracing Radicalism Root in Modern Islamic Movements: A Case of Jama'ah al-Ikhwan al-Muslimun"; ${ }^{12}$ Azyumardi Azra with his research entitled "The Root of Religious Radicalism, The Role of State Officials, 
Religious Leaders, and Teachers in Religious Harmony"; ${ }^{13}$ Abdul Munip's research entitled "Counteracting Religious Radicalism in Schools"; ${ }^{14} \mathrm{Abu}$ Rokhmat 's research entitled "Islamic Radicalism and the Effort of Deradicalization of Radical Understanding"; 15 Ahmad Gaus AF with his research entitled "Mapping Radicalism Problems in Public High Schools in 4 Regions". ${ }^{16}$

From the studies carried out above, no one has examined the characteristics of the interpretation of Al Qur'an verses in Islamic sites which are indicated to adhere to radicalism. The purpose of this research is to reveal the characteristics of the interpretation of the verses of the Qur'an in Islamic sites in Indonesia which are indicated to adhere to radicalism. This study also aims to determine the extent of the implications of interpreting the verses of the Qur'an in Islamic sites against the thoughts of radical Islam in Indonesia. This research is included in the library research category with a media analysis approach focusing on interpreting the verses of the Qur'an which are in Islamic sites in Indonesia. The research is also qualitative in nature. The main data in the research was the interpretation of the Al Qur'an verses in Islamic sites in Indonesia which allegedly adhere to radicalism.

\section{B. Understanding Islamic Sites in Indonesia}

In Indonesia there are many Islamic sites that are indicated by radicalism. In fact, the Ministry of Communication and Information explained, there were at least 26 sites reported, but 4 of them were inactive, 2 sites were duplicates and 1 site was closed. In total, there were 19 sites which have been decided to be blocked. The National Terrorism Management Agency (BNPT) has also released radical Islamic sites in Indonesia. Islamic sites are considered to have spread religious ideas that can disturb Muslims in Indonesia.

$B N P T$ has explained four criteria for Islamic sites that embrace Radicalism. The four criteria are: First, Islamic sites that spread content which invites or directs to anarchist acts and terrorism; second, Islamic sites contain elements of $S A R A$ (ethnicity, religion and race); third, Islamic sites which are takfiri, which are easy to exclude certain people or groups that are not the same as their ideology from Islam; and fourth, Islamic sites that interpret jihad rigidly, jihad is understood as a physical war that can be 
taken place anywhere. It is these four criteria that underlie the BNPT to conclude that Islamic sites containing these four criteria must be closed.

The sites considered to contain radical notions that have been released by BNPT are: Arrahmah.com, Ghur4ba.blogspot.com, Voaislam.com, Panjimas.com, Thoriquna.com, Dakwatuna.com, An-najah.net, Kafilahmujahid.com, Muslimdaily.net, Hidayatullah.com, Kiblat.net, Salam-online.com, Lasdipo.com, Dakwahmedia.com, Muqawomah.com, Lasdipo.com, Gemaislam.com, Aqlislamiccenter.com, Eramuslim.com and Daulahislam.com.

In this study, the researchers will not investigate all of these Islamic sites. Because besides it is too much, it is feared that there will be less focus in the analysis. Therefore, the researchers only focus on five Islamic sites. The five Islamic sites deliberately chose researchers because firstly, the data related to this research can still be accessed and secondly, the Islamic sites that the researchers chose were considered sufficient to represent the radicalism in Indonesia. In addition, not all Islamic sites are focused on interpreting the verses of the Qur'an which lead to radicalism. Because this study specifically examines the characteristics of the interpretation of the verses of the Qur'an carried out by Islamic sites that are considered to contain radicalism. The five Islamic sites are An-Najah.net, hizbuttahrir.or.id, Eramuslim.com, Hidayatullah.com, Lasdipo.com.

1. An-najah.net

The site basically contains Islamic news. There is not much information obtained regarding the history of the birth of this site. However, several sources that have been obtained by this site have entered 22 sites which some time ago was about to be closed by the Ministry of Communication and Information. Even the BNPT has included this site into a site that spreads the notion of radicalism in Indonesia. Even the annajah.net site was once known as the site of the Wahabi terrorist magazine. Although many say that not all Wahhabi are terrorists. However, the news posted on this site strongly contain the enthusiasm to foment jihad. Jihad is understood rigidly and textually.

In the Islamic study column, this site examines various types of Islamic issues. On the website pages, it examines about aqeedah (faith), fiqh (prayer and worshipping rituals) and the issue of jihad. Some of the articles published with the theme of jihad are Jihad is an Instinct in 
accordance with Islamic Teachings, Fishing for Ghirah to Inaugurate Jihad, Securing the Fruit of Jihad, Without Jihad Indonesia Will Never be Exist and many more. In addition to the theme of jihad which has become a central issue in this site, it also raised as a matter of implementing Islamic Laws (laws). A number of articles about the application of Islamic laws are Islamic Ummah Has the Right to Implement a Nation based on Islamic Laws, Harakah Ansharuddin: We Do Jihad to Defend the Implementation of Islamic Laws, DSKS: Surakarta Muslims Synergize in Implementing Islamic Sharia and many more articles calling for the importance of implementing Islamic laws in Indonesia.

\section{Picture 1.}

Example of the Cover of An-Najah Magazine and An-Najah Site Pictures

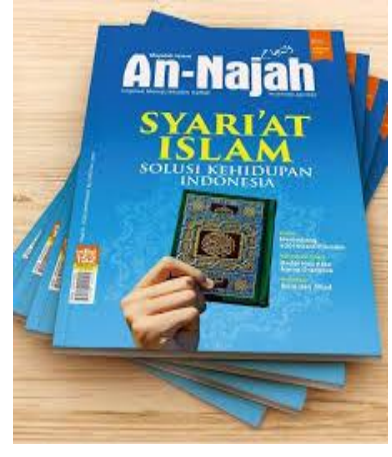

Source:

https://www.google.com/search/
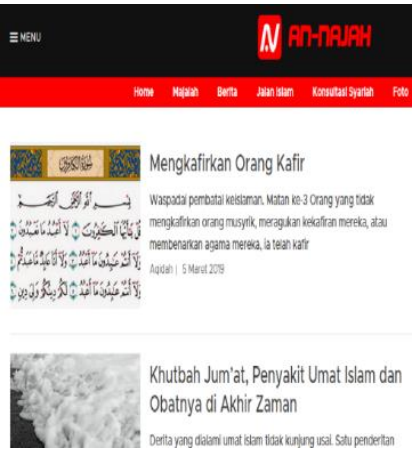

Source:

https://www.an-najah.net/

Moreover, in one of the news stories in online media, this site that promoting the motto "Lifting the Sentence of God" is considered a wahabi terrorist magazine. ${ }^{17}$ Thus, it is not surprising if last year, the government then put this site into one of 26 sites which must be closed. These sites are considered to have spread the notion of radical Islam which is considered to endanger Indonesia. The closure step of these sites is done to prevent the issue of the spread of Islamic State of Iraq and Syria or what is called ISIS through cyberspace.

\section{Hizbut-tahrir.or.id}

The hizbut-tahrir.or.id site is the site of Hizb ut Tharir Indonesia (HTI). This Islamic community organization movement is known as an Islamic community organization which is vigorous in campaigning for the 
implementation of Islamic Laws in Indonesia. HTI has an ideology inviting Muslims to return to the teachings of pure Islam. The religious movement that calls for reviving this religious spirit has spread throughout the world including in Indonesia. ${ }^{18}$ This Hizb ut-Tahrir Indonesia movement represents the view of Islamic revival. ${ }^{19}$ The thoughts that were followed by this group included reviving the spirit of jihad, rejecting the idea of religious freedom, upholding the Islamic Laws and aspiring to establish the Islamic state (Islamic state). HTI Headquarters is at Crown Palace A25, Jl. Prof. Soepomo No. 231, South Jakarta 12390.

The movement called HTU has a site which is still active until today. The site named hizbut-tahrir.or.id with a motto of "Continuing Islamic Life." In the site, Islamic thought, especially the issue of jihad and the application of Islamic law in Indonesia, was intensely promoted. The thoughts in the Al-Qur'an interpretation in the site is published in a magazine called Al-Waie. In the magazine, there is a particular column discussing examining Al Qur'an interpretation. Recently, the tafseer (interpretation) column has been published in a book namely Tafsir AlWaie. ${ }^{20}$

\section{Picture 2.}

One of the Cover of Al-Wa'ie Magazine and HTI Site Address

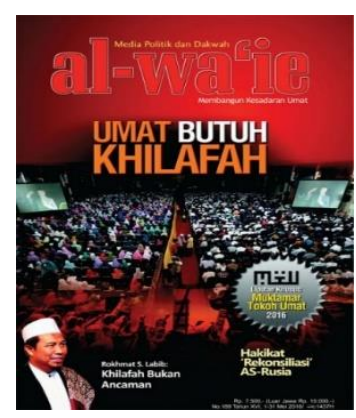

Source:

https://www.google.com/search

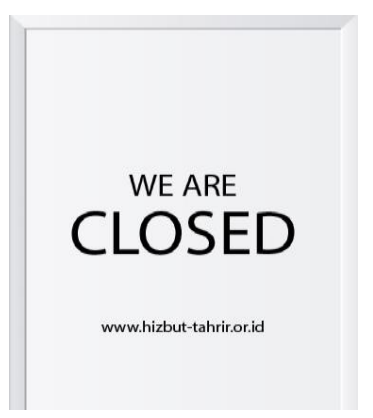

The official site of HTI, www.hizbut-tahrir.or.id, has been closed since Sunday 23 July 2017

Some of the following articles are closely related to Al Qur'an interpretation the Serious Threats for Islamic Laws Refusing People; Threats to Sharia Refusing People; Faith, Hajj and Jihad; Islam Refuses the Idea of Religious Freedom; Illegitimacy of Implementing Non-Islamic Laws, People's Sorrow without Islamic State and many more. Almost all 
interpretation themes brought in eth articles are the call upon physical jihad and total implementation of Islamic laws.

\section{Eramuslim.com}

The following is eramuslim.com. the site has a motto of "Islamic Media Referral". The director of site is MM. Nasution and the editor in chief is Riza Dirgantara. The office of the site is located at Perum Pratama $B 3 / 10-B o g o r$. The site is an Islamic site promoting news and information to the society especially to the Moslems in Indonesia.

Eramuslim.com was established on Agustus tahun $1^{\text {st }}$ 2000. In addition to Bogor, the site also has an office in Cibubur, East Jakarta. The establishment of the site began along with the rise of the internet in the 2000s in which internet media became an interesting forum if it could be used in spreading Islamic values. Starting from this period, MM. Nasution, who has a business background, wants to make an online propaganda media which now is famous for eramuslim.com. MM. Nasution, in addition, is an alumny of Trisakti university. ${ }^{21}$

\section{Picture 3.}

Logo and Figure of Eramuslim Magazine and Eramuslim Site Pictures

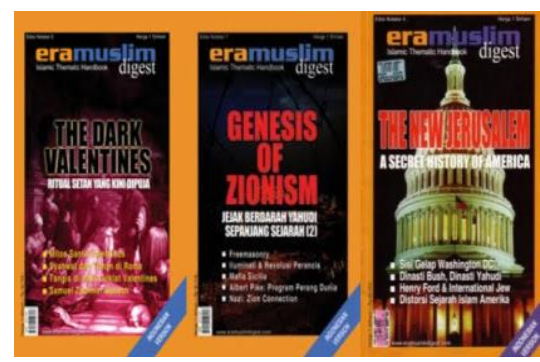

Source: ttps://www.google.com/search/

Accessed 05 March 2019

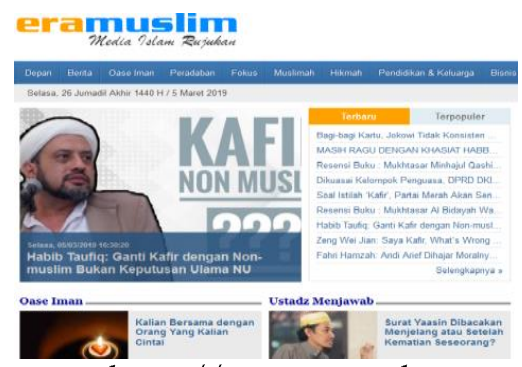

Source: https://www.eramuslim.com/

Accessed 05 March 2019

In the site, there are many studies starting from Islamic economy, Islamic thoughts, education, family, miracles of al-Qur'an and Sunnah (Prophet's Teachings) and the interpretation of al-Qur'an. The site began to be a hot discussion in Indonesia after it was included into the list of Islamic sites which were going to be closed by ministry of information. Previously, the site has also been a hot discussion because it has ever mentioned about Syi'ah as astray. ${ }^{22}$ It is not surprising that the site was blocked for the second times. Before it was declared as radical site by the government in January 2016, in March 2016, the site has been blocked because it was considered to spread radical thoughts. But after a number of 
media sent protests to the BNPT that they were not a radical site, Eramuslim and number of other sites were reopened.

4. Hidayatullah.com

Hidayatullah.com is a site which was a name if a magazine called Suara Hidayatullah (Hidayatullah Voice) or was usually abbreviated as Majalah Hidayatullah. The magazine is one of the business entities in the Orams Hidayatullah area that works on the press field. This magazine is managed by PT Lentera Jaya Abadi, a business entity owned by Hidayatullah Community Organization. Hidayatullah is an Islamic mass organization in Indonesia. Its name comes from two words in Arabic: hidayat / hidayah (guidance) and Allah, which means God's guidance. Hidayatullah was founded on January 7, 1973 in Balikpapan in the form of a pesantren (Islamic boarding school) by Abdullah Said (the late). After some periods of time, the school then developed with various business charities in the fields of social, da'wah (preaching), education and economics and even spread to various regions in all provinces in Indonesia. Through the National Conference I on July 9-13 $3^{\text {th }} 2000$ in Balikpapan, Hidayatullah changed the form of the organization into a community organization (mass organization) and declared itself an Islamic struggle movement.

\section{Picture 4.}

One of the cover Suara Hidayatullah Magazine and Hidayatullah.com Site Pictures

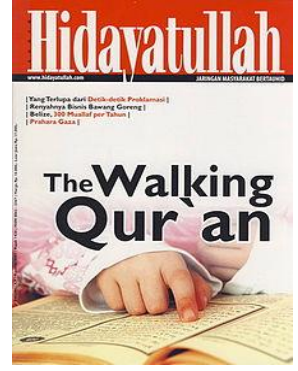

Source:

https://www.google.com

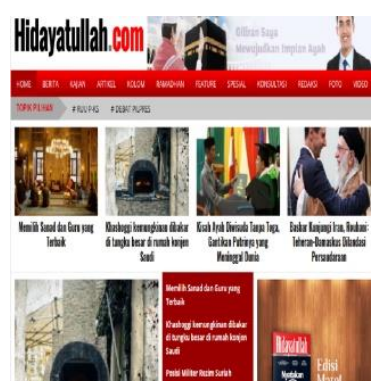

Source:

https://www.hidayatullah.com

Initially, this magazine was only in the form of a bulletin produced by several santri (Students in Islamic Boarding School) at Hidayatullah Islamic Boarding School in Balikpapan. Considering how strategic the qalam bil preaching (preaching through written media) through mass 
media is, the bulletin continues to be developed until it finally takes the form of a magazine. Hidayatullah Magazine initially relied on printed media but by following the development of the technology era, the magazine developed into online media under the name of hidayatullah.com. The site contains the problems and dynamics of da'wah, both in Indonesia and the world. In the site, there is also an interview rubric with famous figures, $\mathrm{Al}$ Qur'an and Hadits studies, and heroic struggles of da'i (preachers) around Indonesia until family and nation problems. In addition to reviving online media, the site still publishes the printed media until nowadays. Within a month, the magazine has published $50.000-$ 55.000 copies. The magazine has spread throughout the country from Banda Aceh to Merauke. The magazine has a headquarter office in Surabaya, Jawa Timur. Hidayatullah.com in an online form is a news portal both national dan international carrying the motto of "Spreading the Truth.” The site was founded in 1996 under the management of Hidayatul Media Group. ${ }^{23}$

\section{Lasdipo.com}

The Lasdipo.com site is one of the sites that are on the block list of the Directorate General (Ditjen) of Informatics Applications, Ministry of Communication and Information (Kemenkominfo) in 2016. The blocking plan was carried out by the Ministry of Communication and Information at the request of the BNPT because the site was considered to be related to Islamic State supporters in Iraq (ISIS). The site is an online Islamic news site that contains Islamic news, both in Indonesia and abroad. The site has a motto of "Mature in Plan and Accurate in Action".

The site also has a sort of running text whose sentences are nuanced with promoting the spirit such as "TIME TO GET THE LINE!" There are also sentences prmotoing awareness of one of religious group. The site also contains writings showing the spirit of Islamic state establishment. In addition, jihad issues are always promoted. The site also does not hesitate to criticize the government in some articles such as, "MUI Secretary General: Disband Densus (Detachment) 88 for Its Violation of Humanity Boundary" and "Tommy Soeharto: PKI Is the One Managingthe Country!" and many more. 


\section{Picture 5.}

Site Pictures Lasdipo.com

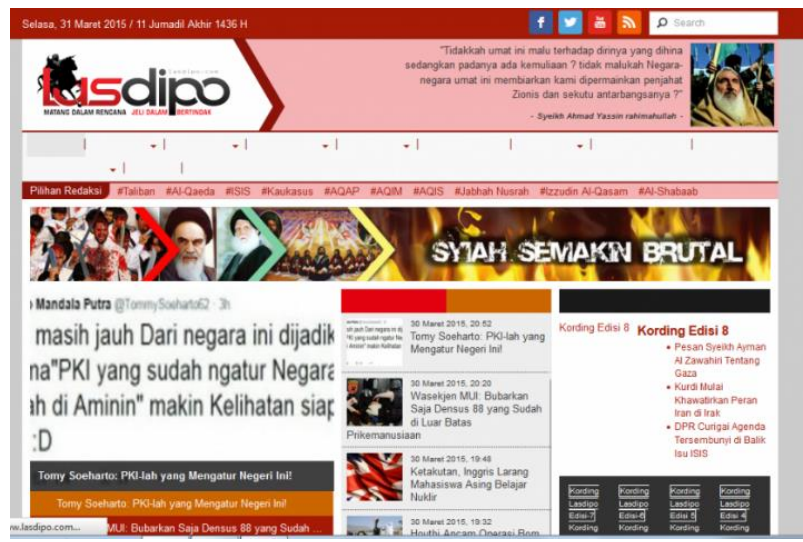

Source: https://www.republika.co.id/ Accessed 05 March 2019

As the previous mentioned sites, the site also allegedly taught and spread radical Islam. Thus, it is not surprising that the government include the site into several sites that had to be closed because it was feared it could have an impact on the development of radicalism in Indonesia. Although there are some parties who have also criticized the government's act in closing these sites. One of them is Journalism Lecturer, Faculty of Da'wah and Communication at Sunan Kalijaga UIN Yogyakarta, Hamdan Daulay, who considered the government's plan to block several Islamic media sites as a backward step for freedom of expression. ${ }^{24}$ Some articles connote that the site spreads radical notions such as an article entitled Nasyid Jihad Lanallah Yaa Tughmatal Kafirin ${ }^{25}$ ), لَناً اللهُ يَاً طُغْنَةَ الْكَافِرِيْنِ (When is the Time for Upholding Islamic Laws?,26 "Phase and The Steps of Jihad Prayer Implementation, ${ }^{27}$ and many more.

\section{Al-Qur'an Interpretation Methods in Islamic Sites}

Talking about the method of interpretation, it has been offered by commentators many times. Many reviewers of the Qur'an refer to the methodology developed and introduced by al-Farmawi. Al-Farmawi in his book entitled al-Bidayah fi al-Tafsir al-Maudhu'i, mapped the method of interpreting the Qur'an into four parts: tahlili, ijmali, muqaran and maudhu'i. First, the method of tahlili, is a method of interpretation which intends to explain the content of the verses of the Qur'an from all aspects. ${ }^{28}$ 
The method of tahlili or what is named by Baqir al-Sadr as the tajzi'i method, is a method of interpretation that the exegete tries to explain the contents of the verses of the Qur'an from various aspects by observing the sequence of verses of the Qur'an as stated in in mushaf (scripture). ${ }^{29}$ The second is the ijmali method. It is a method of interpretation that interprets the verses of the Qur'an by expressing global meaning. ${ }^{30}$ In it the interpretation, the exegete describes verse by verse in the order in the mushaf and then explains the global meaning contained in the verse being discussed. Then, the third is the muqaran method. It is to investigate the interpretation of the verses of the Qur'an which are written by a number of interpreters namely, ${ }^{31}$ by examining the interpretations by the exegete that have interpreted the verses that will be interpreted through this method. ${ }^{32}$ Meanwhile, the last method is maudhu'i (thematic) method which collects Al Qur'an verses containing the same meaning and altogether one problematic topic and then arranges the verses according to the chronology and the descent of the verses. ${ }^{33}$

After conducting the analysis on the Islamic states studied in the study, it can be found that the method used in interpreting $\mathrm{Al}$ Qur'an verses in the sites is by using theatic method (maudhu'i). They carry the interpretation based on certain themes. The themes they brought is close to the recent issues circulating in the middles eastern countries such as jihad, Islamic Laws implementation, Islamic state, and many others. For example, in an-najah.net site which published article entitled "Islamic Ummah of Indonesia Bare the Rights to Base State's Foundation on Islamic Laws,"34 Jihad Obligation on the eyes of A True Mujahid, "35 "It Is Hypocrite to Choose Non-Believers as Guardian"36 "Wala and Bara Consequences of Al Maidah 51,"37 "Ulama Vs Ruler: Who Is the Real Ulil Amri (Leader)?"38 "Encouraging the Ghirah (Spirit) of Jihad, ${ }^{39}$ and many more. The refusal issues on Pancasila which is regarded as not in line with Islamic laws they carried. For example an article entitled "When Pancasila Becomes Ruler's Lord”. 40

In hizbut-tahrir.or.id site, there are some themes of $\mathrm{Al}$ Qur'an interpretation which are published in special column. The site has a special interpretation column named Tafsir Al-Waie. The writer in the column is Rokhmat S. Labib. The themes are "The Laws for The Highest Rulers of Thagut," 41 "Serious Threats for People Who Refuse Islamic Laws," 42 “Threats for Islamic Laws Blockage Maker!"43 'The Illegitimacy of Non- 
Islamic Laws Implementation," "Th "The Illegitimacy of of Obeying Laws besides Allaah's Laws (Interpretation of QS At-Taubah [9]: 31),"45 "Islam Refuses the Idea of Religious Freedom," 46 "Faith, Hijrah (Moving), and Jihad," 47 and "Syura Is Not Democracy. ${ }^{48}$

The same thing happen in the other sites in which the method they carry is thematic method; departing from certain themes they want to interpret. Besides using verses with verses, they also use the prophetic traditions in interpreting the verse. Previously, they also explained the verse of Nuzul asbabun (chronology). However, not all of these Islamic sites have deducted every verse of the Nuzul asbabun. Only one site often refers to the nuzul asbabun of a verse, namely hizbut-tahrir.or.id, while others rarely mention it. Most of these sites ignore the methodical steps in interpreting the thematic Qur'an. They focus more on the tendency to convey their ideological messages. This is unfortunate because the moral message of the verse that is interpreted can deviate. In this case, the verses taken are interpreted as if only as a matter of legitimacy or justification.

At least there are seven steps an interpreter must take in order to use this thematic method:49 First, choose or determine the Qur'anic problem which will be studied using mawdhu'i (thematic) method. Second, trace and collect verses related to the problems that have been set, the Makiyyah (revealed in Mecca) and Madaniyah (revealed in Medina) verses. Third, compile these verses in a coherent manner according to the chronology of their time, accompanied by the knowledge about the background of the descent of the verse or asbab al-Nuzul. Fourth, investigate the correlation (munasabah) of the verses in each letter. Fifth, arrange the discussion themes in an appropriate, systematic, perfect, and intact framework. Sixth, complete the discussion and description with the hadith, if necessary, so that the discussion is more perfect and clearer. And seventh, study these verses thematically and comprehensively by collecting verses that contain similar meanings, compromising between the meaning of 'am and khash, between the mutlaq and muqayyad, synchronize the verses that are born seems contradictory, explain the verses of nasikh and mansukh, so that all the verses meet on one conclusion, without differences and contradictions or acts of coercion on some verses to meanings that are actually incorrect. 


\section{Interpretation Characteristics of Islamic Sites in Indonesia}

Speaking of characteristics in an interpretation, what is meant here are the characteristics and features of the interpretation products that they produce. If it is perceived from the style, there are several things in the world of interpretation that can be mentioned, such as linguistic style, figh style, theological style, literary style, social-community style and others. However, in this study, the researchers do not map the features as mentioned above. Meanwhile, the researchers examine the characteristics of the other side, namely the prominent characteristics of each product interpretation.

From the analysis that has been carried out on the five sites that the researchers have examined, the researchers found four characteristics that characterize the interpretation of the verses of the Qur'an carried out by the five sites. The four characteristics are as follows:

\section{Al-Qur'an as Ideology Legitimation Tool}

The first characteristic is the product of interpretation produced by Islamic sites discussed in the research which is an interpretation that focuses more on the side of the ideology of the group. Thus, every verse that is intended to be interpreted or chosen to be interpreted is certain verses that have a connection with their ideology. The interpretations they produce are not from problems that should depart from social problems. In fact, if it is investigated from the history of Al Qur'an revelation, most of them were revealed related to the problems faced by Prophet Mohammad SAW and Islamic ummah at the time of the revelation. Every verse of the Qur'an that are revealed are usually an answer to the problem that arises.

From the argument above, it can be generalized that the verses taken and then interpreted or understood in these sites are more identical as means of legitimacy or used as a tool to justify their ideas and thus, the moral message contained behind each verse that is interpreted is not conveyed because this model of interpretation emphasizes the ideas they stretched and is not from the verse interpreted. Instead, they are interpreted according to the ideology they have. For example, when they drive surah or verses which according to them are related to their ideology support in applying Islamic law. They also criticize the government by saying that Pancasila has become an "idol" of the government. According to them the establishment of the Pancasila as a single principle has been 
deemed as aiming at marginalizing the political role of Muslims who at that time were eager to fight for the aspirations of Islam in the life of the nation and state. They assume that Muslims see the existence of a single principle as "de-politicization of Islam" carried out by a regime that is drunk with power. ${ }^{50}$

Therefore, many certain Islamic groups, including the sites studied in the research, criticize the current government model as the 'taghout' (idol) model of government. ${ }^{51}$ They assess the current system of government and the Indonesian economy as a system of wrong governance. The current system of Indonesian government for them is a system of "Modern Jahiliyah" (Modern era of Arab where Mohammad first revealed the Al Qur'an) which must be replaced with an Islamic system. ${ }^{52}$ Observing the condition of Indonesia, they offer a solution to the idea of establishing an Islamic State ${ }^{53}$ because, according to them, only with the establishment of an Islamic State, the system of government in Indonesia can be totally replaced with a system of Islamic government. ${ }^{54}$ Meanwhile, moving towards this change obliged to establish Islamic political parties. ${ }^{55}$

If the Islamic government can be realized with the leader of a Khilafah Islamiyyah, then they can apply Islamic law in totality. Almost all the sites that the authors review here call for the application of Islamic law in Indonesia. For example, on the website hizbut-tahrir.or.id, which aggressively campaigns for the application of Islamic law, it is stated that:

"The threat of severe torture for those who believe His instructions and turn away from them. While in the worldly life, it is still possible to propose a million reasons to deny sharia and turn away from it. They also still apply various laws and living systems to their passions. However, their attitude will certainly not occur in the hereafter ... Really there is no reason to reject and deny His sharia. Those who reject sharia only suffer their own misery." 56

In the site of lasdipo.com, an article entitled "When Do We Implement Islamic Laws $?^{57}$ it mentions that:

"Upholding Islamic law which includes the practice of ubudiyah and hudud punishment for the benefit of the ummah is the aim of the Mujahideen fighting. Self-servitude to God will feel perfect if 
the Laws law has been implemented and is stable in the area of the Muslims." 58

The site of hidayatullah.com also mentions:

It is ironic, if people claim to be Muslim, have an Islamic ID card, but there are still those who think that Islamic law cannot be applied or them with the opinion saying that "Sharia is not ready to be implemented " because applying Islamic laws is "mandatory", whenever it is... Islamic law is always compatible and it is a human nature, anytime and anywhere ... Therefore, it is certain, Islamic law is very human or humanist viewed from any side and direction. Therefore, compared to Western merchandise called HAM (human rights), Islamic law is more feasible to be "earthed"." 59

On the site of Eramuslim.com, it is said that:

"Even though in plain view Islamic punishments seem cruel and violent, but in fact, Islamic laws, in determining punishment, is more intended as a means to achieve public benefit and safeguard it ... it is clear that punishments in the form of cutting hands, stoning, killing or whipping do not violate human rights, on the contrary, the punishment aims to protect human rights and provide true justice, and ensure security and order in society.." 60

The site of an-najah.net also proposed an argument that supports Islamic laws implementation by stating that:

"If there are parties saying that, "This is not an Islamic State, if you want to enforce Islamic law in this country, and do not like the condition of Indonesia now, please leave" ... Muslims must fill this country with Islamic laws ... So, whatever the story, revealing the historical journey of this nation and country, more than that, Indonesia is actually a country based on Islam, at least for the adherents who are obliged to run and enforce Islamic law in this nation." ${ }^{61}$

2. The loss of verses context

In interpreting the verses of the Qur'an, it is important to pay attention to the historical social context in which the verse descends. Studying the history of the problem surrounding the verse down is an important thing that cannot be ignored by every exegete. Abdullah Saeed, 
one of the leaders of contemporary interpreters, said that the sociohistorical context is very important to make the verses of legal ethics meaningful and relevant to contemporary Muslim life. ${ }^{62}$ Saaed also confirmed that:

"The context of the socio-historical al-Qur'an in the pre-Islamic period and the early Islamic period cannot be ignored. To understand this context, a person needs detailed knowledge of the life of the Prophet in both Mecca and Medina; social, economic, political and legal climate; and norms, laws, customs, institutions and values that applied in the region, especially in the Hijaz. Including residence, clothing and food; social relations, including family structure, social hierarchy, prohibitions (restrictions) and rites (ceremonies). The importance of each of the above aspects is shown by the frequency of the mention in the Qur'an."63

The idea of Saeed emphasizes the importance of seeing asbabun nuzul (chronology) of verses and studying the cases that surround the verse revelation because it is very important to find the meaning of the essence of the verse. Interpreters who ignore the socio-historical context of the verse will lose the meaning of the nature of the verse. As a result, the product of interpretation is far from the purpose of the verse. This is what the researchers found in the interpretation of the verses of the Qur'an carried out on Islamic sites studied in the research. There are many who ignore the understanding of the context of the socio-historical context of the verse and fail to "earth" their products of interpretation in the contemporary era.

As stated by M. Amin Abdullah:

"According to the philological study, any text, including religious texts, does not just appear from the sky. Text does not arise from the "empty" space of culture. Religious texts and texts - whatever their form - are composed, compiled, imitated, altered, created by the author in accordance with the level of human thought when the texts are compiled and cannot be separated completely from the socio-political and socio-cultural upheaval that surrounds them." ${ }^{64}$ 
For example, when they understand the verses about jihad, they understand that the jihad which is intended is physical jihad, war and murder. As they said;

"After blaspheming in front of opponents of Islam, Allah ordered to do hijrah (moving) and ordered them to fight with swords, decapitate the neck of anyone who opposed, belied and defied the Qur'an. If so, how urgent is iron as a bearer of da'wah. So, it seems obvious that armed jihad is the lawsh of Allah which is obliged to the Muslims after optimizing da'wah. "65

Likewise, when they understand QS. Al-Maidah [4] verse 49. According to them, this verse explains the obligation of Muslims to implement Islamic law in total, indiscriminately with non-Islamic ones.

"This verse requires Muslims to decide cases with laws originated from the Al-Qur'an and as-Sunnah (prophet's teachings). The party that is obliged to be the object of the application of sharia law is not limited to Muslims, but also infidels. According to some interpreters, this provision does nasakh (invalidates the law) QS al-Maidah verse 42 which gives a choice to the Prophet to decide the case of the infidels or not. In that verse, Allah SWT. said: Fahkum baynahum aw a'ridh 'anhum (Decide the matter between them, or turn away from them)." 66

In understanding the verses of the Qur'an, the author emphasizes the importance of distinguishing between Arabization and Islamization because not everything that comes from Arab culture is Islam. So, it is feared that everything are ke-Arab-araban (act like and refer to Arabs) are applied and forced when understanding a verse causes problems because every nation and culture between one and the other is not the same. To become a Muslim, one does not have to be an Arab. To become an Islamic state, a nation does not have to be like an Arab country. This is what the interpreters of the verses such as in the site of Islam studied in the research have forgotten. They forget the socio-historical context of the verse. As a result, the interpretation product is unable to provide answers or solutions because it is unable to touch the social problems where the mufsir (interpreter) interprets the Qur'an.

3. Carrying the Jihadis Theme Interpretation 
What is meant by the theme of jihadist interpretation were the themes of the interpretation of the Qur'an which raised the theme of the Khilafah Islamiyah, both regarding jihad, the application of Islamic laws and others. For example, when they interpret the theme of jihad as when they understand QS. Al-Baqarah [2] verse 218. The word jihad in this verse is understood as jihad in terms of physical warfare. Below, the researcher quoted one of their understanding - not to say legitimacy - towards this verse:

"Believers must not be satisfied and stop when sharia has been applied in the country they live in. They are required to carry out da'wah and spread Islam throughout the world. This is what must be used as the basis of foreign policy for the Islamic State. To carry it out, jihad is defined as tharîqah or method. It is noteworthy, the obligation of new jihad can be carried out when the population of a country rejects one of two offers: entering Islam or becoming a dhimmi infidel who is subject to the government of Islam. When rejecting one of them, it means that they have become physical barriers that hinder Islamic da'wah. To eliminate the physical obstacle, it must be with physical activity too, namely with jihad fi sabilillah. If the country succeeds in being conquered by jihad, then its status changes to become part of Dar al-Islam. Sharia is also applied totally in that country. "67

In other sites it is also stated that physical jihad must be upheld. According to them it is not enough nowadays if jihad only relies on oral method but it must be carried out with the sword. For example when they interpret the following verse:

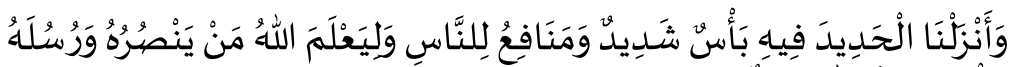

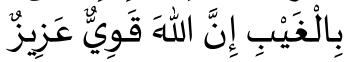
"........ And we created iron in which there are great strengths and various benefits for humans, (so that they use the iron) and so that God knows who helped (His religion) and His apostles when Allah did not see him. Indeed, Allah is Strong, Mighty"(Surat alHadid [57]: 25).

The word "iron" in the verse was understood that Allah has warned that iqomatuddin is not merely a matter of preaching bilhal, oral, written and demonstration, but also by functioning of iron as a helper and 
defender of da'wah of li'ilaaikalimatillah. ${ }^{68}$ Some of the statements posted on the site when driving the verse above also invite attitudes that show violence. It is mentioned below,

"After blaspheming in front of opponents of Islam, Allah ordered to do hijrah (moving) and ordered them to fight with swords, decapitate the neck of anyone who opposed, belied and defied the Qur'an. If so, how urgent is iron as a bearer of da'wah. So, it seems obvious that armed jihad is the laws of Allah which is favored to the Muslims after optimizing da'wah." ${ }^{19}$

On the lasdipo.com site, many excerpts of articles calling for jihad are displayed. For example, an article entitled "Endurance Is Important in Jihad. ${ }^{170}$ In this site, it is affirmed that jihad is something that must be done, must be started and done anytime, anywhere and by anyone.

"Ants will condemn those who are reluctant to do jihad. And fish in the sea only ask forgiveness for those who want to fight only. Because they are the ones who teach virtue to humans and protect those virtues with their swords, spirits and blood. And in fact, the ladybugs in their burrows complained to Allah about the tyranny of those who were sitting at home and reluctant to jihad. Because of their reluctance to go to jihad, the sky stops decreasing the rain, the plants on the earth decrease, the drought widens and the hunger hits ... Surely we are fighting nothing but seeking merit. While the great and abundant reward of jihad requires patience, truthfulness and sincerity of heart. "71

Even on this site, they frankly offer a nasyid (Islamic song) calling on jihad with the title of "Lanallah Yaa Tughmatal Kafirin ( لَنَاً اللهُ ياً طُغْنَة (الْكَافِرِيْن () This Nasyid is equipped with Arabic text and Indonesian subtitles. The Nasyid is Arabic and if the meaning of the subtitles of the Nasyid is understood, the meaning is indeed as if inviting anger to war.

In addition to spelling out verses and also containing inspirational information on jihad, in this case, it also quoted one of the verses which inflame the importance of jihad:

من ابتغى الجنة قام الليالي Whoever wants jannah (heaven), he wakes up at night 


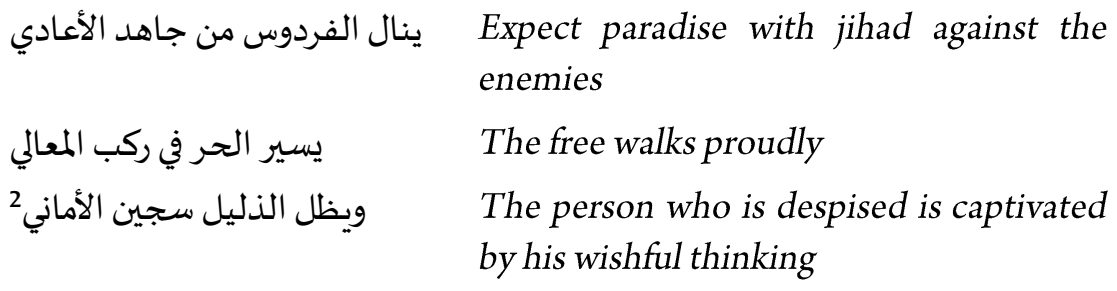

They are also vigorous in carrying out the campaign to totally implement Islamic law in Indonesia. The ideological message in campaigning on the issue of the application of Islamic laws often drives the verses of the Qur'an. Their understanding of the verses of the Islamic laws is fueled by their ideological frenzy. For example when understanding QS. Al-A'raaf verse 96:

"Islam laws are noble laws, it will always bring blessings to anyone and wherever it is applied... In the Kitabul Iman by Abdullah al Wazaf, he writes sentences that are so well said for those who claim to be Muslim but reject the laws of Allah that "Only ignorant Muslims who want to waste the laws of God and replace it with human laws". Thus, a person is said to be a fool when he claims to be a Muslim but rejects Islamic laws in his country. And it is enough to say that people are stupid, if they defend desperately man-made laws because in fact, God's law is the noble one again brings mercy to all nature. ${ }^{\text {73 }}$

Moreover, in an-najah.net website, it is clearly stated that Muslims in Indonesia have the right to set the foundation of the State based on Islamic law ${ }^{74}$ although they acknowledge that the application of Islamic law is still a sensitive issue in Indonesia. As a matter of fact, some people reject Shari'a or Islamic laws and consider (and even hear the term) it as something "scary". ${ }^{75}$

Similarly, when they understand QS. Al-Maidah [4] verse 49. According to them, this verse explains the obligation of Muslims to implement Islamic law in total, indiscriminately with non-Islamic ones.

${ }^{2}$ Read, Read, www.lasdipo.co, "Inilah Ideolog Jihad Yang Tak Anda Kenal” on http://www.lasdipo.co/kajian/telaah/2015/08/25/inilah-ideolog-jihad-yang-tak-andakenal.html/ 14 Februari 2017. 
"This verse requires Muslims to decide cases with laws originating from the Al Qur'an and as-Sunnah (Prophet's teachings). The party that is obliged to be the object of the application of sharia law is not limited to Muslims, but also infidels. According to some interpreters, this provision mentions (invalidates the law) QS alMaidah verse 42 which gives a choice to the Prophet to decide the case of the infidels or not. In that verse, Allah SWT said: Fahkum baynahum aw a'ridh 'anhum (Decide the matter between them or turn away from them)."76

They also explained how important it is to uphold the khilafah before applying Islamic law:

"If the reality of Islamic laws is related to the position of man as caliph (ruler) on earth, then it can be stated: the position of the people of Rasulullah saw can only be a caliph (in the sense of QS. Al-Baqarah [2]:30) if his life is under the auspices of the Caliphate led by a caliph (in the sense of sharia, ie: people who represent the Ummah to run the government, authority, and the application of Islamic laws.) because only when there is a caliph then all the laws of Allah can be carried out totally." ${ }^{177}$

Those are some descriptions of the characteristics of interpretations of the verses in this Islamic sites. In this section, the researchers then refer to the characteristics of jihadist interpretations which are façade products which contain themes about the Islamic Caliphate state and about the application of Islamic laws in Indonesia. In addition, the issue of carrying out jihad was also strongly campaigned on the sites.

3. Producing Objectivistic Revivalist Interpretation

The meaning of the product of interpretive revivalist objective typology is an interpretation or understanding of the textual-ideological Qur'an. ${ }^{78}$ In the sense that the understanding of the textual-ideological Qur'an is the understanding of the Qur'an which returns to the character of interpretation that is static, ahistorical, textual and patriarchal bias. Every product of the interpretation they carried brings its own mission. In addition to the textual products of interpretation, behind the interpretations, they carry ideological message they want to convey to the reader. In the view of the sites that researchers have analyzed, the Qur'an in 
the present era must be understood in accordance with the era in which the Qur'an was revealed without regard to the context in the present era.

The model of interpretation that they do departs from their own ideology, rather than departing from the text which is then brought to the surface of social-community problems. Some of the ideological missions that they wish to convey include establishing a khilafah Islamiyyah state, totally repeating Islamic law, calling for physical jihad (war, raising swords, spilling blood and the like), rejecting official government which is considered secular jahiliyyah and so on. This group seems to favor a model of government and society as it was at the time of the Prophet Muhammad. This group aspires to turn Indonesia into a civil society. For them, Islam in the time of the Salaf is the most perfect Islam, still pure and clean from various additions or mixtures (bid'ah) which are seen as polluting Islam. ${ }^{80}$ Islam in the era of the Prophet according to this group is ideal Islam and must be imitated in the present era without regard to the social political and cultural conditions in the present that have been far different from the period of the Prophet. ${ }^{81}$

The product of interpretation that is produced is usually a rigid interpretation and patriarchal bias. The product model of interpretation with this revivalist subjectivist paradigm is less friendly to women. Women want to be laid off again. Women do not deserve to be active in social and government, what else is to become a leader. This paradigm model is not in line with the principle of gender equality. The interpretive paradigm that they built is opposite the paradigm model of the modernist interpretation that is more accommodating to the contemporary science. The paradigm of objectivist interpretation of revivalists closes itself against the development of contemporary sciences outside the Qur'an. For example, this group openly rejects the use of hermeneutics as one of the aids in interpreting the Qur'an. Meanwhile, the modernist interpretation group paradigm is more open and accepting.

\section{E. The Qur'anic Interpretation of Islamic Sites and Their Implications for the Mind of Radical Islam in Indonesia}

In analyzing the impacts caused by thought products resulted from the sites in Indonesia, the researchers used 2 theories of media influence namely Priming theory and Syringe theory. 


\section{Priming Theory}

Priming theory is a process in which mass media focuses on some issues and not on other issues and thus changes the evaluation standards used by the audiences to assess the social reality it faces. Priming can also be called activation of media stimuli from one active thought connected to other thoughts in the brain. ${ }^{82}$ Besides, this theory also explains that the media encourages the formation of thoughts that are connected with what is displayed in the media itself. For example, there is a tendency to mimic the scenes of violence displayed in the media in other people in the real world. ${ }^{83}$

\section{Syringe theory}

In the history, it was noted that the newspaper published by William Randolph Hearst had resulted in a war between the United States and Spain in 1898. The newspaper reported that the sinking of a US warship called Maine, in Havana Harbor was a huge and seemingly excessive act of the Spanish army and thus, war could not be avoided. After the sinking of the United States Navy warship in the port of Havana, political pressure from the Democrats and industrialists encouraged the government of Republican, President William McKinley, to raise the flag of war with Spain. But later, it was discovered that the sinking of the US warship was not due to an attack by Spanish soldiers. ${ }^{84}$

From the example between America and Spain above, it can be seen that the influence of the media is very strong in encouraging changes in the human mind, with impacts and processes that are so great as hypodermic or bullets that glide at high speed. ${ }^{85}$ As in the example above, another more obvious example is the speech made by the leader Adolf Hitler, via public radio. ${ }^{86}$ Hitler's speech finally became a vital factor for the beginning of the Holocaust in World War II.

Both of the theories emphasize how the role of media is very important in changing and forming one's mindset or society. The media is so strong in changing the paradigm of thinking that it can move certain people or groups of people to act or behave in a certain way. The same is true of Islamic sites in Indonesia. They themselves admit that the role of the media in delivering da'wah is greater than just taking up arms on the battlefield. Through online Islamic media, they spread their ideas and ideas. Their aspirations about the importance of establishing an Islamic 
State, the application of Islamic law, jihad and others they spread through the media. The influence of the media, both print and electronic, is undeniable and has a lot of influence on its readers.

Another example is several terrorism cases in Indonesia that were successfully overtaken by Detachment 88 found several evidence tools such as jihadist books or jihadist guidelines. For example, in October 2014 the Special Detachment (Detachment) of 88 Indonesian Police Headquarters succeeded in arresting suspected terrorists in Pasangkayu District, North Mamuju Regency, West Sulawesi. In these arrests, books on Jihad were found. Next, in Mojokerto, in December 2015, police in the arrest of suspected terrorism also found books about jihad. In February 2016, in Malang, the police also managed to confiscate books on jihad, including 'Tarbiyatul Jihadiyah', 'Knowing the Teachings of the Prophet Is Not Terrorists', 'Unknowingly Becoming an Infidel', and 'Radicalization Movement'. Not only about jihad, the officials also found the symbol of ISIS. $^{87}$

From some of the examples above, it is very obvious that the influence of media, both printed and electronic, can affect one's thinking and behavior. Someone who often reads or is considered to be addicted to participation in one of the Islamic sites can have an affected paradigm of thinking. For example, he was a guest speaker who found that he recently listened to recitation lectures on one of the radios. Then he began to justify the contents of the recitation he was listening to. At first he said "I often listen to the radio. The contents of the lecture are actually good. I like the contents. But it often blames other groups. Other different groups are illegitimated. I thought for a long time how come it was like this. Then I decided not to listen to the radio anymore. ${ }^{88}$ Different respondent also said that he began to frequently ask the teachings he had been practicing so far. He began to doubt the Islam he had embraced so far. It seems that this resource person has begun to be affected. So, on several occasions he often asked about the teachings of Islam which are true. ${ }^{89}$

Those are some facts of how the influence of the media is very strong on one's mindset and behavior. The media turned out to have a huge impact in spreading certain ideologies by certain groups. As a community and at the same time as parents, it is important to be involved in supervising the people closest to them so that they do not easily fall into certain unwanted groups. Because after all, in the present era the role of 
media, especially gadgets, the influence cannot be stopped. Children can easily access sites that can threaten their religion.

After reviewing and analyzing the five Islamic sites, a conclusion can be taken in which the ideological messages they convey through online media can influence someone's mindset and behavior. The campaign of Khilafah Islamiyyah Nation, Islamic laws implementation as well as jihad by swords must be government's serious attention and society. It is possible that many radical Islamic sites in Indonesia which freely spread their ideology can give a widespread impact of radicalism for Indonesian people.

\section{F. Conclusion}

Based on the analysis on the five Islamic sites above, 4 criteria of $\mathrm{Al}$ Qur'an interpretation have been found; (1) Al Qur'an interpretation is only a mean of ideological legitimation. The resulted interpretation is only for supporting ideas and opinions of their own group, (2) in interpreting $\mathrm{Al}$ Qur'an verses, they neglect verses' contextualization as well as verses' socio-historical background. Thus, the moral lessons of the verse are failed to convey, (3) their interpretation always carries out jihadis interpretation. Their interpretation products are interpretation which characterize a campaign of Khilafah Islamiyah nation, Islamic laws implementation, refusal of secular governmental system as well as physical jihad (swords lifting for a war), (4) interpretation typology resulted from their interpretation is a subjective revivalist typology, an interpretation or comprehension of Al Qur'an which is textual-ideological. The interpretation means a recall of static, ahistoric, textual, and patriarchic bias. According to the findings, it can be concluded that $\mathrm{Al}$ Qur'an verses interpretation in radical Islamic sites gives great influence for the readers or followers. In the theory of media influence namely Priming and Jarum Suntik (Syringe) theories which emphasizes that media role is very important in changing and forming someone or society's mindset. Media is very powerful in changing thinking paradigm that it can even move someone or a group of society to do or behave in a certain way. In conclusion, it is obvious that the interpretation of the $\mathrm{Al}$ Qur'an brought by Islamic sites indicated as radical sites can give effect to radical Islamic understanding especially in Indonesia. [.] 


\section{Acknowledgement}

The article is a research result funded by LP2M of UIN Sunan Kalijaga Yogyakarta year of 2016. Thanks to LP2M of UIN Sunan Kalijaga Yogyakarta for funding the research.

\section{References}

Abdullah, M. Amin. "Arkoun dan Kritik Nalar Islam” in Johan Hendrik Meuleman (peny.), Tradissi Kemordenan dan Metamodernisme: Memperbincangkan Pemikiran Muhammad Arkoun, Yogyakarta: LKiS, 1996.

Al-Farmawi, Abd. Al-Hayy. Metode Tafsir Mawdhu'i: Suatu Pengantar, terj. Surya A. Jamrah, Jakarta: PT RajaGarafindo Persada, 1994.

An-najah.net, "Umat Islam di Indonesia Berhak Tetapkan Dasar Negara Berlandaskan Syariat Islam” on https://www.annajah.net/berita/ummat-islam-di-indonesia-berhak-tetapkandasar-negara-berlandaskan-syariat-islam/ 14 Februari 2017.

Azra, Azyumardi "Akar Radikalisme Keagamaan Peran Aparat Negara, Pemimpin Agama dan Guru Untuk Kerukunan Umat Beragama” Makalah in workshop "Memperkuat Toleransi Melalui Institusi Sekolah", held by The Habibie Center at Hotel Aston Bogor, on May $14^{\text {th }} 2011$.

Bakri Syamsul "Islam dan Wacana Radikalisme Agama Kontemporer" in Jurnal Dinika, Vol. 3 No. 1, Januari, 2004.

Dzulhadi, Qosim Nursheha. "Membumikan Syariat Islam" on https:// www.hidayatullah.com/artikel/tsaqafah/read/2012/10/28/2374 /membumikan-syariat-islam.html/ 15 Februari 2017.

Fealy, Greg \& Aldo Borgu, Local Jihad: Radical Islam and Terrorism in Indonesia, Canberra: 2005, Australian Strategic Policy Institute.

Febriansyah, Reza. Radikalisme Berlatar Belakang Agama in Masyarakat: Studi Kasus pada Ormas FPI Pelembang). Skripsi, Universitas Sriwijaya, Palembang 2013

Gaus AF., Ahmad "Pemetaan Problem Radikalisme di SMU Negeri di 4 aerah” in Jurnal Maarif, Vol. 8, No. 1, Juli 2013. 
Hadi, Muhammad Yusran. "Hukuman Cambuk Tidak Melanggar HAM, Tanggapan terhadap Amnesty International" on https:// www.eramuslim.today/ berita/ laporan-khusus/ hukumancambuk-tidak-melanggar-ham-tanggapan-terhadap-amnestyinterntional.htm\#.WKQFkfjcBpI/ 15 Februari 2017.

hidayatullah.com, "Syariat Islam di tengah Kedengkian Propaganda Barat" on https://www.hidayatullah.com/artikel/tsaqafah/read/2014/ 03/27/18929/syariat-islam-di-tengah-kedengkian-propagandabarat.html/ 14 Februari 2017.

hizbut-tahrir.or.id, "Hukuman Bagi Penguasa Thaghut" on https://hizbuttahrir.or.id/?s=thaghut/ 15 Februari 2017.

Islah, "Dialektika Tafsir al-Qur'an dan Praktik Rezim Orde Baru" in Disertasi PPs UIN Sunan Kalijaga Yogyakarta, 2014.

Khaeruman, Badri. Sejarah Perkembangan Tafsir al-Qur'an, Bandung: Pustaka Setia, 2004.

Kumpulan Pidato Tokoh Dunia, "Pidato Adolf Hitler Tentang Pernyataan Perang terhadap Uni Soviet 22 Juni 1941" on http:// kumpulanpidatotokohdunia. blogspot.co.id/ 2015/11/ pidatoadolf-hitler-tentang-pernyataan.html/ Akses 15 Februari 2017.

Labib, Rokhmat S. "Ancaman Bagi Penghalang Syariah!" on https://hizbut-tahrir.or.id/2011/07/14/ancaman-bagipenghalang-syariah/13 Februari 2017.

. “Ancaman Keras Bagi Penolak Syariah" on https://hizbuttahrir.or.id/2011/11/29/ancaman-keras-bagi-penolak-syariah/13 Februari 2017.

"Hukum Bagi Penguasa Thagut" on https://hizbuttahrir.or.id/2016/12/26/hukuman-bagi-penguasa-thaghut/ 13 Februari 2017.

"Iman, Hijrah, dan Jihad" on https://hizbuttahrir.or.id/2008/12/30/iman-hijrah-dan-jihad/13 Februari 2017. . "Islam Menolak Ide Kebebasan Beragama" on https://hizbuttahrir.or.id/2008/10/03/islam-menolak-ide-kebebasanberagama/13 Februari 2017. 
. "Keharaman Menaati Hukum Selain Hukum Allah (Tafsir QS atTaubah [9]: 31)” on https://hizbut-tahrir.or.id/ 2008/04/01/keharaman-menaati-hukum-selain-hukum-allahtafsir-qs-at-taubah-9-31/13 Februari 2017.

. "Keharaman Menerapkan Hukum Non-Syariah" on https://hizbuttahrir.or.id/2007/05/02/keharaman-menerapkan-hukum-nonsyariah/13 Februari 2017.

. "Syura Bukan Demokrasi” on https://hizbut-tahrir.or.id/ 2009/04/11/syura-bukan-demokrasi/13 Februari 2017.

. Tafsir al-Wa'ie, Jakarta: Wadi Press, 2010.

Mizan, Aguk Irawan "Melacak Akar Radikalisme Dalam Gerakan Islam Modern: Kasus Jama'ah al-Ikhwan al-Muslimun” in Jurnal Analisis, Vol. XI, No. 1, Juni 2011.

Mubarak, M. Zaki Genealogi Islam Radikal di Indonesia: Ideologi, Pemikiran dan Prospek Demokrasi, Jakarta: LP3ES, 2008.

Munip, Abdul. "Menangkal Radikalimse Agama di Sekolah" in Jurnal Pendidikan Islam, Vol. 1, No. 2, Desember 2012.

Mursalin, Ayub dan Ibnu Katsir, "Pola Pendidikan Keagamaan Pesantren dan Radikalisme: Studi Kasus Pesantren-pesantren di Provinsi Jambi” in Jurnal Kontekstualita, Vol. 25, No. 2, 2010.

Nahimunkar.com, "Gara-gara Memberitakan Sesatnya Syi'ah, Eramuslim Disebut Erakafir" on https://www.nahimunkar.com/gara-garamemberitakan-sesatnya-syiah-eramuslim-disebut-erakafir/ Februari 2017

Noor, Hasan M. "Islam dan Terorisme dan Agenda Global in Perta Vol. 5 No. 22.

Pranata, Rudi “An Indonesian's View of Islamic Radicalisme” in tempo 1521,2005

Prisgunanto, Ilham. Praktik Ilmu Komunikasi Dalam Kehidupan Sehari, Jakarta: Teraju, 2004.

Putra, Erik Purnama. "Lasdipo.com, Salah Satu Situs yang Dinilai Radikal" on http://www.republika.co.id/berita/nasional/umum/15/03/31 /nm1f6q-emlasdipocomem-salah-satu-situs-yang-dinilai-radikal/ 13 Februari 2017. 
Rahmat, M. Imdadun Arus Baru Islam Radikal: Transmisi Revivalisme Islam Timur Tengah Ke Indonesia, Jakarta: Erlangga, 2005.

- Arus Baru Islam Radikal: Transmisi Revivalisme Islam Timur Tengah Ke Indonesia, Jakarta: Erlangga, 2005.

Redaksi An-Najah, "Ketika Pancasila Menjadi Berhala Penguasa” on https://www.an-najah.net/fokus/ketika-pancasila-menjadiberhala-penguasa-bag-4-selesai/ 9 Februari 2017.

. "Kewajiban Jihad Dimata Seorang Mujahid Sejati," on https://www.an-najah.net/jalan-islam/kewajiban-jihad-dimataseorang-mujahid-sejati/ 9 Februari 2017.

. "Memancing Ghirah Memantik Jihad" on https://www.annajah.net/event-info/citizens-jurnalism/memancing-ghirahmemantik-jihad/9 Februari 2017.

. "Munafik Lebih Memilih Wali Orang Kafir" on https://www.annajah.net/tak-berkategori/munafik-lebih-memilih-wali-orangkafir/9 Februari 2017.

. "Ulama Vs Penguasa: Siapa Ulil Amri?" on https://www.annajah.net/edisi-134/9 Februari 2017.

- "Ummat Islam di Indonesia Berhak Tetapkan Dasar Negara Berlandaskan Syariat Islam" on https://www.annajah.net/berita/ummat-islam-di-indonesia-berhak-tetapkandasar-negara-berlandaskan-syariat-islam/9 Februari 2017.

. "Wala dan Bara Konsekuensi Al Maidah 51" on https://www.annajah.net/tak-berkategori/wala-dan-bara-konsekuensi-al-maidah51/9 Februari 2017.

Redaksi Lasdipo.com, "Fase dan Tahapan Pensyariatan Ibadah Jihad” on http://www.lasdipo.co/kajian/taushiyah/2015/05/25/fase-dantahapan-pensyariatan-ibadah-jihad-bag-2.html/ 13 Februari 2017.

. "Kapan Saatnya Kita Menegakkan Syariat Islam" on ?http://www.lasdipo.co/media/video-kajian/2015/08/25/videomanhaj-kapan-saatnya-kita-menegakkan-syariat-islam.html/ 13 Februari 2017.

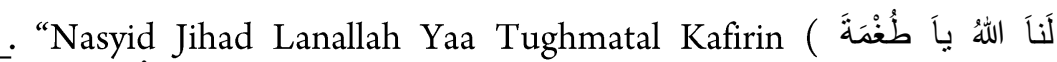
(الْكَافرِيْن 
rilis/2016/04/22/nasyid- jihad- lanallah-yaa-tughmatal-kafirin/ 13 Februari 2017.

Rizal Syamsul, "Radikalisme Islam Klasik dan Kontemporer: Membanding Khawarij dan Hizbut Tahrir" in Jurnal Al-Fikr, Vol. 14, No. 2, 2010.

Rokhmat, Abu "Radikalisme Islam dan Upaya Deradikalisasi Paham Radikal” in Walisongo, Vol. 20, No. 1, Mei 2012.

Saeed, Abdullah. Paradigma, Prinsip dan Metode Penafsiran Kontekstualis atas Al-Qur'an, terj. Lien Iffah Nafatu Fina dan Ari Henri, Yogyakarta: Lembaga Ladang Kata, 2016.

Salafytobat.wordpress.com "Majalah An-Najah : Majalah Teroris Wahabi" on https://salafytobat.wordpress.com/2010/05/13/teroris-solomajalah-an-najah-majalah-teroris-wahabi-salafi-palsu-solo/ $\quad 13$ Februari 2017.

Sefrianita, Risda. "Peran Situs www.eramuslim.com dalam Menyosialisasikan Nilai-nilai Keislaman" in Skripsi Fak. Ilmu Dakwah dan Ilmu Komunikasi UIN Syarif Hidayatullah, 2011.

Shihab, M. Quraish. Membumikan al-Qur'an: Fungsi dan Peran Wahyu dalam Kehidupan Masyarakat, Bandung: Mizan Pustaka1996.

Malang, Surya. "Inilah Daftar Buku Jihad yang Disita Densus 88" on http:// suryamalang.tribunnews.com/2016/02/21/inilah-daftarbuku-jihad-yang-disita-densus-88/ 15 Februari 2017.

Syamsuddin, Sahiron. Hermeneutika dan Pengembangan Ulumul Qur'an, Yogyakarta: Pesantren Nawesea Press, 2009.

Wardaya, Baskara T. Indonesia Melawan Amerika Konflik PD 1953-1963, Yogyakarta: Galang Press, 2008.

Wikipedia, "9 Teori Dampak Media” on https:// id.wikipedia.org/ wiki/ 9_Teori_Dampak_Media/15 Februari 2017.

Wiktorowicz, Quintan Radical Islam Rising: Muslim Extremisn in the West, Boulder, Toronto and Oxford: Rowman \& Littlefield Publishers, Inc., 2005

Woodward, dkk., "Muslim Education, Celebrating Islam and Having Fun As Counter-Radicalization Strategies in Indonesia”, Perspectives 
on Ter: A Journal of the Terrorism Research Initiative, 4.4. (2010): 42 .

www.an-najah.net "Memancing Ghirah Memantik Jihad" on https://www.an-najah.net/event-info/citizensjurnalism/memancing-ghirah-memantik-jihad/ 14 Februari 2017.

. "Ketika Pancasila Menjadi 'Berhala' Penguasa” on https://www.annajah.net/fokus/ketika-pancasila-menjadi-berhala-penguasa-bag4-selesai/ 15 Februari 2017.

. "Umat Islam di Indonesia Berhak Tetapkan Dasar Negara Berlandaskan Syariat Islam" on https://www.annajah.net/berita/ummat-islam-di-indonesia-berhak-tetapkandasar-negara-berlandaskan-syariat-islam/ 15 Februari 2017.

www.eramuslim.com, "Menolak Syariat Islam adalah Sebuah Kebodohan" on https://www.eramuslim.today/suara-kita/suara-pembaca/ menolak-syariat-islam-adalah-sebuah-kebodohan.htm\#. WKMxhPJcBpI/14 Februari 2017.

www.lasdipo.co, "Inilah Ideolog Jihad Yang Tak Anda Kenal" on http://www.lasdipo.co/kajian/telaah/2015/08/25/inilahideolog-jihad-yang-tak-anda-kenal.html/ 14 Februari 2017.

"Kapan Saatnya Kita Menegakkan Syariat Islam?" on http://www.lasdipo.co/media/video-kajian/2015/08/25/videomanhaj-kapan-saatnya-kita-menegakkan-syariat-islam.html / 15 Februari 2017.

"Keteguhan Itu Penting Dalam Berihad" on http://www.lasdipo.co/kajian/telaah/2016/02/26/keteguhanitu-penting-dalam-jihad.html/ 14 Februari 2017.

. "Keteguhan itu Penting dalam Berjihad" on http:// www.lasdipo.co/kajian/telaah/2016/02/09/keteguhan-itupenting-dalam-jihad-bag-1.html/ 14 Februari 2017.

Zuhdi, M. Nurdin. "Dialog Intelektual Tafsir Nusantara: Melacak Trend Penafsiran Al-Qur'an di Indonesia dalam Kancah Pemikiran Tafsir Kontemporer (2000-2010)" in Makalah The Annual International Conference on Islamic Studies (Aicis), Iain Raden Intan Lampung, November 1-4, 2016. 
. "Kritik terhadap Pemikiran Gerakan Keagamaan Revivalisme Islam di Indonesia" in Akademika Jurnal Pemikiran Islam, Vol. XVII, No. 02, 2012.

. "Kritik Terhadap Penafsiran Al-Qur'an Hizbut Tahrir Indonesia" in Akademika: Jurnal Pemikiran Islam, Vol. 18, No. 2, 2013.

- "Kritik Terhadap Pemikiran Keagamaan Gerakan Revivalisme Islam", in Sosiologi Agama Jurnal Ilmiah Agama dan Perubahan Sosial, vol. 5, No. 1, Januari-Juni 2013.

- Pasaraya Tasir Indonesia: dari Kontestasi Metodologi hingga Kontekstualisasi, Yogyakarta: Kaukaba Dipantara, 2014.

Interview with Mijo in Bantul, on Januari 2017.

Interview with Win in Bantul, on Januari 2017. 